\title{
River morphology and evolution of the Barind Tract, Bangladesh
}

\author{
*Md. Bazlar Rashid ${ }^{1}$, Md. Sultan-Ul- Islam ${ }^{2}$, Md. Badrul Islam² \\ ${ }^{1}$ Geological Survey of Bangladesh, 153 Pioneer Road, Segunbagicha, Dhaka 1000, Bangladesh \\ ${ }^{2}$ Department of Geology and Mining, University of Rajshahi, Rajshahi 6205, Bangladesh \\ *Email: bazlarrashid@ymail.com
}

\begin{abstract}
The Barind Tract is an elevated Pleistocene Terraces (about 11-48 m amsl) in northwestern Bangladesh and is widely accepted Tract to have been evolved from tectonic upliftment and /or exists as an erosional geomorphic feature. Some part of the Barind Tract bears the characteristics of morphological origin but some areas are providing evidences of tectonic upliftment. The present study is an attempt to interpret the morphological characteristics of the rivers in the area and tried to unveiling the processes that are responsible for the evolution of the Tract. River morphology are interpreted from satellite images and field mapping and are used to relate neotectonic activities occurred in the area. The river forms U-shaped valleys in floodplain areas whereas these are V-shaped within the Barind Tract. The rivers and valleys on the Tract are also comparatively more straight, incised and entrenched, and rivers are tightly meandered, more localized, form paired and unpaired terraces, and antecedent in nature, whereas, the rivers in the floodplain are either meandering, braided or anastomosing drainage channels. Along the boundary between Barind and floodplain the rivers form asymmetric valley with steeping bank along the tract sides. The width/ depth (W/D) ratios of these rivers are much lower within or near to the Tract than the nearby floodplain. The rivers flowing from the Himalayas change their morphology, trend, nature etc. near and within the Tract. Some of the N-S flowing rivers turned towards southeast and southwest directions to maintain slope of the uplifted Tract. These are the indication of structural control of these rivers as well as the tectonic origin of the Barind Tract rather than only geomorphic origin. Earthquakes in this region in the recent past also support the same view about structural control and neotectonic activities.
\end{abstract}

Keywords: River morphology, evolution, Tract, Bangladesh

Received: February 30, 2015

Revision accepted: June 3, 2015

\section{INTRODUCTION}

The geomorphic evolution of the elevated Barind Tract is a matter of debate among geologists as well as geomorphologists. Some groups of the geologists have the opinion that the Barind Tract represents tectonically uplifted surfaces (Fergusson 1863, Hirst 1916, Morgan and McIntire 1959, Khandoker 1987, Alam 1995) and some others suggest that the Barind Tract represents an erosional geomorphic feature (Monsur 1990, 1995). It is one of the many Pleistocene terraces present within the Bengal Basin (Morgan and McIntire 1959, Khan 1991 and Huq et al. 1991) that spreads over 9,324 sq km area of parts of the greater Rajshahi, Dinajpur, Rangpur and Bogra Districts in Bangladesh, and about 2650 sq. km of the Maldah District of West Bengal in India (SPARRSO 1984). The tract is mainly an alluvial terrace, which abruptly merged into recent floodplain. Previously, these red soil horizons and sedimentary sequence have been named as The Barind Clay Residuum (Alam et al. 1990) avoiding its inherent sedimentological characteristics of deopositional environment. After detailed study it is renamed as the "Barind Clay" Formation as a whole and as different local informal name (Alam 1993, Alam amd Paepe 1996, Alam et al. 1997a, b; Monsur 1990, 1995; Monsur et al. 2001). This area is being facing different problems like land use and urban development, with variable dimensions in the groundwater for irrigation. To accommodate heavy urbanization and population rise, the area has undergone tremendous environmental degradation resulting from a mismatch between adopted land use and morphotectonic considerations. The present study tried to unveiling the processes that are responsible for evolution of the Tract with interpretation of river morphology. The study area lies between latitudes $24^{\circ}-26^{\circ} \mathrm{N}$ and longitudes $88^{\circ}-89^{\circ} \mathrm{E}$ (Fig. 1). A large part of this area belongs to the exposed Pleistocene deposits, and rests are either the floodplain, alluvial fan, channels, flood basins of the number of rivers flowing through the area. The study area is about $340 \mathrm{~km}$ long and about 205 $\mathrm{km}$ wide covering an area of about $35,000 \mathrm{~km}^{2}$.

\section{GENERAL GEOLOGY}

The Bengal Basin occupies a major part of Bangladesh. Tectonically, this part of the Bengal Basin is divided into two major divisions (a) the Precambrian Rangpur Platform and (b) the Bengal Foredeep (Khan 2002). The study area is located at the northwestern part of Bangladesh falls in the Precambrian Rangpur Platform of the Bengal Basin. It is an alluvial plain with elevated Pleistocene terraces, which slope towards the south and southeast. 


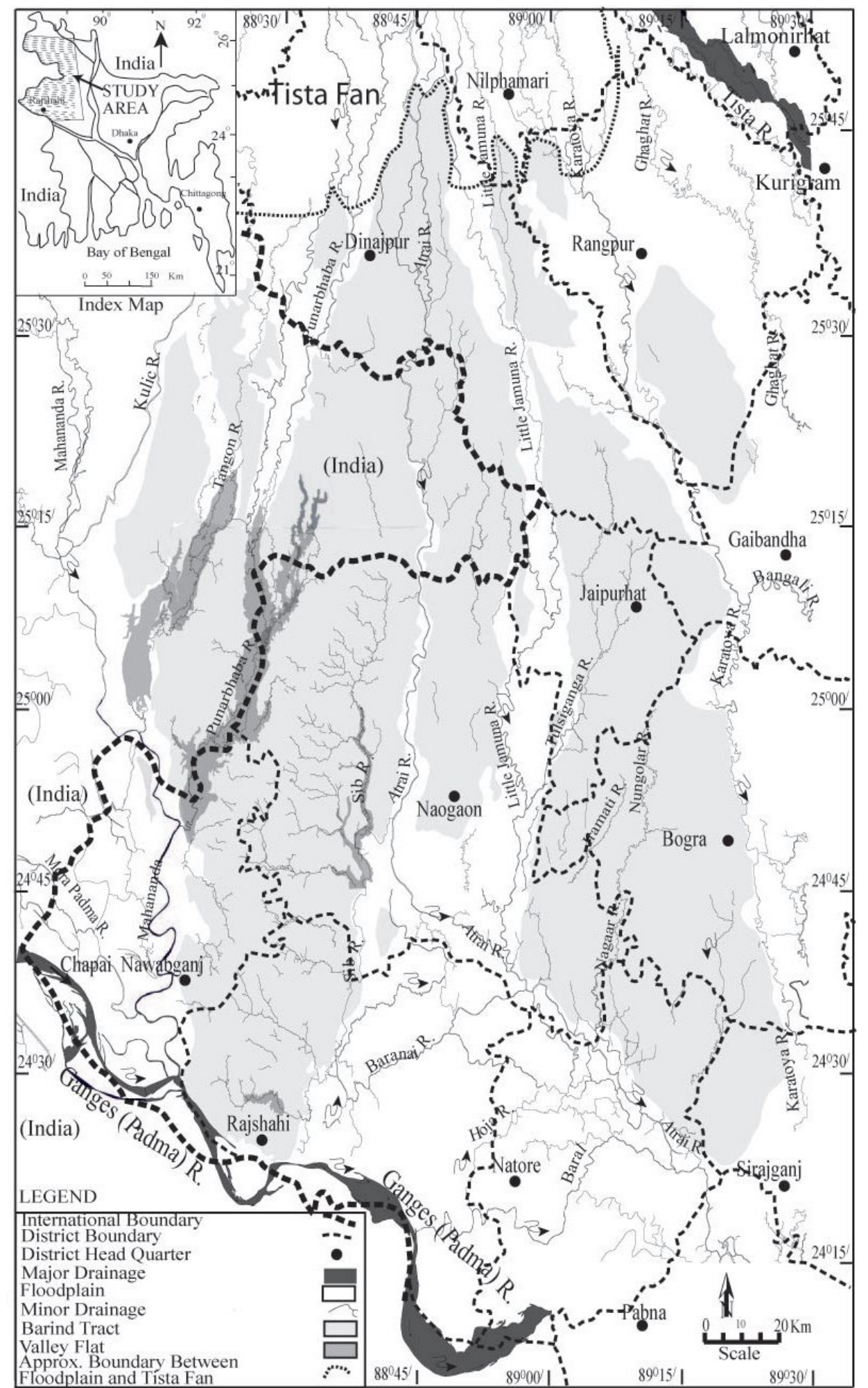

Fig. 1: Location map of the study area.

\section{PHYSIOGRAPHY}

The study area falls into three major physiographic surfaces- the Pleistocene Barind Tract, Holocene channelfloodplain complexes and Holocene Himalayan piedmont plain (Tista Fan) (Figs. 1, 2). The Barind Tract is exposed on a slightly elevated land (about 11-48 m amsl) in comparison to the surrounding floodplains. It forms inliers within floodplain and is criss-crossed by different rivers having highly dissected topography. The Tract is mainly an alluvial terrace, which abruptly merged into Recent floodplain. The Holocene channel-floodplain complexes are lies along the Ganges (Padma), Mahananda, Punarbhaba, Kulic, Tangon, Atrai, Sib, 


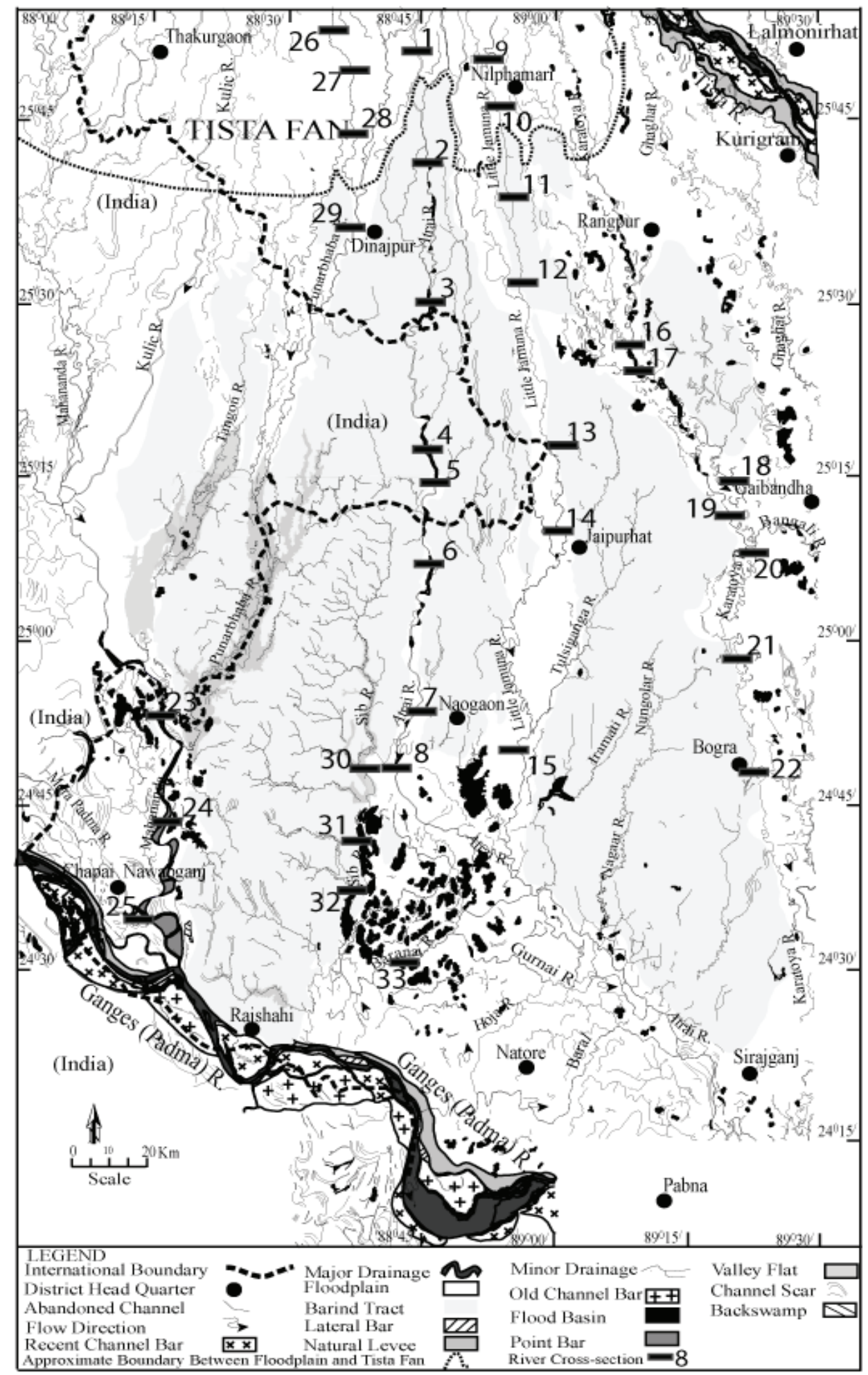

Fig. 2: Drainage map of the study area.

Little Jamuna, Tulsiganga, Baral, Nagar, Karatoya, Ghaghat and Tista Rivers. The elevations of these floodplains are ranges from about 8-23 m. All the floodplains of the study area are deeply inundated annually. The Tista Fan has been delineated over the northern part of the study area. After emerging from the foot-hills of the Himalayas, this fan has a criss-crossed network of channels with shifting river courses. The low to moderate sinuosity of the Mahananda, Tangon, Punarbhaba, Atrai, Karatoya, Ghaghat and Tista Rivers indicate that this fan radiate on the gently slopping plains. The elevation of this fan ranges from about 30-45 m with regional slopes towards southwest and southeast. 


\section{DRAINAGE OF THE AREA}

The Ganges (Padma), Mahananda, Punarbhaba, Kulic, Tangon, Atrai, Sib, Little Jamuna, Tulsiganga, Baral, Nagar, Karatoya, Ghaghat and Tista are the main rivers in the study area (Figs. 1, 2). All the rivers are flowing roughly N-S, NESW and SE directions (Figs. 1, 2). The Barind Tract shows the tightly meandering entrenched channels with dendritic drainage pattern, whereas, the rivers in the floodplain are either meandering, braided or anastomosing drainage channels. Two types of drainage channels are present in the Barind Tract. The first one has incised and highly meandering channels. These channels are longer and more sinuous and flow roughly towards south. The channels of the second type are shorter and less sinuous. These flows towards the S-SW direction in the eastern Barind Tract, SW and SE directions in east-central and western Barind Tract, E-W, W-E, S-N, SW and SE directions in the west-central Barind Tract.

\section{RIVER MORPHOLOGY}

The drainage is the connecting link between the erosional and depositional parts of the system (Bull 1977) and therefore the drainage significantly influences the morphology of an area. Drainage system adapts to the changes of surface slope and these have the potential to record information about the evolution of structure like, faults and folds (Ollier 1981, Leeder and Jackson 1993). The morphology of rivers reflects a balance between the erosive power, the stream flow and the erosional resistance of the bed and bank materials. Morphological changes of an alluvial channel can occur as a result of changes in water discharge, sediment load, sediment type and gradient. Tectonic activity significantly controls river patterns and their behaviors (Burnett and Schumm 1983, Gregory and Schumm 1987, Holbrook and Schumm 1999, Marple and Talwani 2000, Valdiya and Rajagopalan, 2000; Sinha-Roy 2001, Schumm et al. 2000). Neotectonic movements are reflected only in those geomorphic features that react to smallest changes of slope. When stream channel and terraces are offset along faults these exhibit remarkable effects (Wallace 1967, Stevens 1974). Many of the major rivers of the world follow structural laws and major geo-fracture systems and have adjusted to tectonic activity (Melton 1959, Potter 1978).

Fluvial anomalies, such as local development of meanders or braided pattern, local widening or narrowing of channels, anomalous ponds, marshes or alluvial fills, variation in levee width or discontinuous levees, and any anomalous curve or turn etc. are possible indicators of active tectonics in a alluvial plain (De Blieux 1951, 1962; Leopold and Wolman 1957, Ollier 1981, Ouchi 1985, Singh and Ghosh 1994, Jain and Sinha 2005). Migrating and alternating bars forming, a sinuous thalweg, a highly sinuous channel of equal width, frequent transition of meander-braided natures etc. are also the indicators of active tectonics (De Blieux 1951, 1962; Leopold and Wolman 1957, Ollier 1981, Ouchi 1985, Singh and Ghosh 1994, Jain and Sinha 2005).

The drainage pattern in the Bengal Basin as a whole has been greatly controlled by the tectonic features of the basin. Considerable evidence of significant tectonic movements has been recorded within and along the boundary of the basin in Late Tertiary and the Quaternary times (Priyadarshi 2009).

Structural implication in the study area is reflected in the drainage pattern on both of the floodplain and the Barind Tract. The Barind Tract shows the tightly meandering entrenched channels with dendritic drainage pattern, whereas, the rivers in the floodplain are either meandering, braided or anastomosing drainage channels (Figs. 2-8). The incised channels and valleys with terraces, straight alignments of rivers through the Barind Tracts like the Atrai, Little Jamuna, Karatoya, Mahananda etc., southwestern flow of all the rivers in the eastern Barind Tract instead of flowing to the nearby Karatoya River in the east, recent disconnection of the Nagar River from the Karatoya River and almost abandonment of the strongly flowing large Karatoya River, narrowing and entrenched nature of large Barind valleys, stepping on bank of the entrenched valleys, few disconnected and beheaded former valleys and gradual dry up when reaching flat low lands, highly raised terraces, narrow rills and gully like features, changing of river courses, shifting of rivers like Ganges (Padma), Brahmaputra, Tista, Atrai, Kosi etc. (Rashid et al. 2015, Figs. 2-8) are the obvious indications of the upliftment of the Barind Tract.

To identify structural features and neotectonic evidences, cross-sections of drainages have been drawn along different parts of the study area. Mean sea level (msl) is considered as zero level while constructing cross-sections. Remarkable variation in valleys, especially their shapes are considered as the evidence of neotectonics. The Atrai, Karatoya, Little Jamuna, Sib, Mahananda and Punarbhaba Rivers show U-shaped valleys in floodplain areas, V-shaped valleys in the Barind Tract and nearly V-shaped or one sided steeping valleys near to the Barind Tract (Figs. 3-8). It is interesting that a river shows U-shaped before entering into the Barind Tract, $\mathrm{V}$-shaped within the tract and U-shaped again in floodplain areas (Figs. 3-8). The primary response of rivers to tectonics is manifested as change in channel slope, while secondary changes are reflected in aggradation/degradation and variations in channel morphology (Jain and Sinha 2005). In general, uplift regions are characterized by river entrenchment, low W/D ratio and degradation processes, whereas subsidence causes shallow channel, aggradation, frequent flooding and presence of low-lying area or marshy land (Ouchi 1985, Holbrook and Schumm 1999, Valdiya and Rajagopalan 2000, Marple and Talwani 2000). 
River morphology and evolution of the Barind Tract, Bangladesh

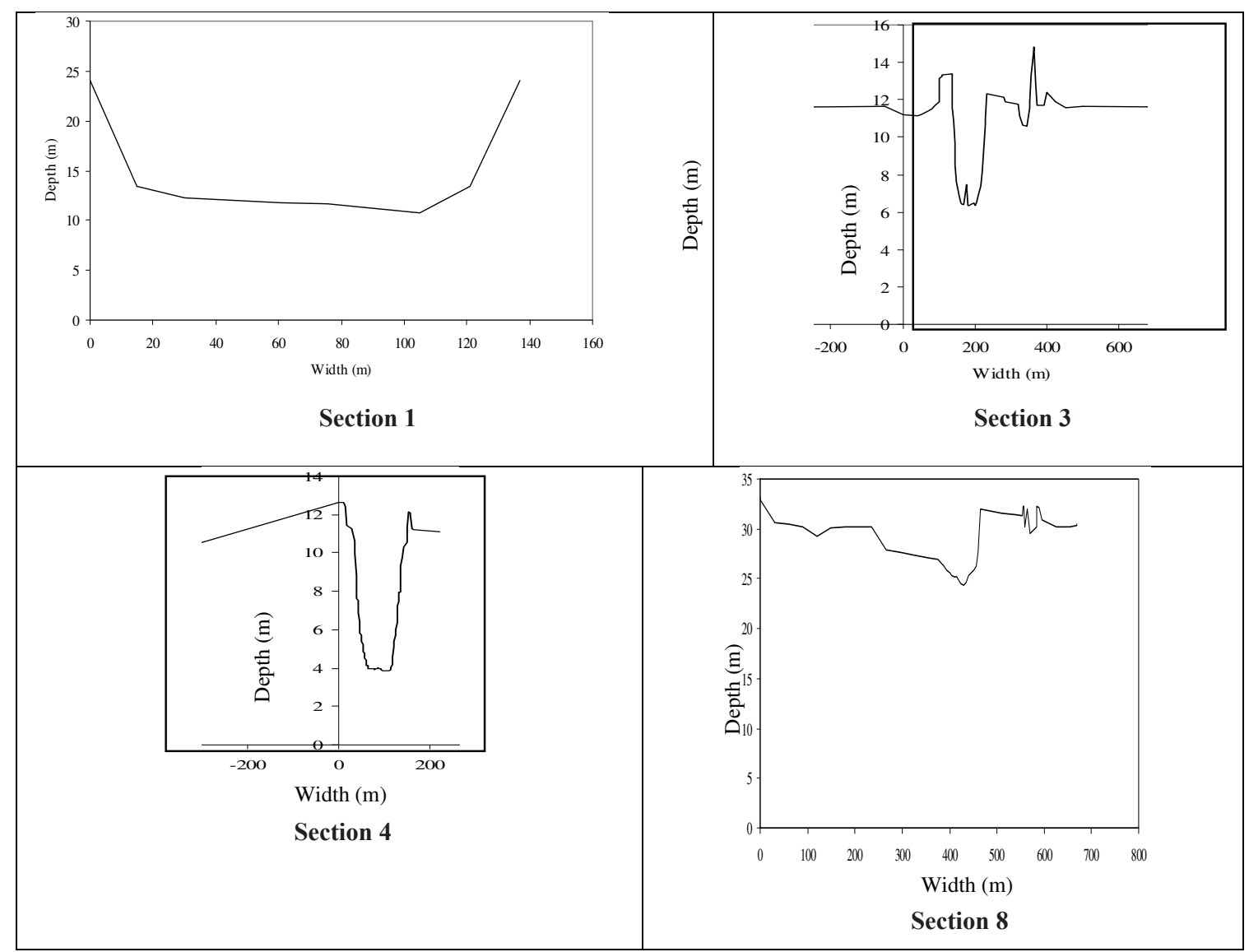

Fig. 3: Cross section and valley character of Atrai River (Section 1, 3,4, 8). (Index Map Fig. 2)

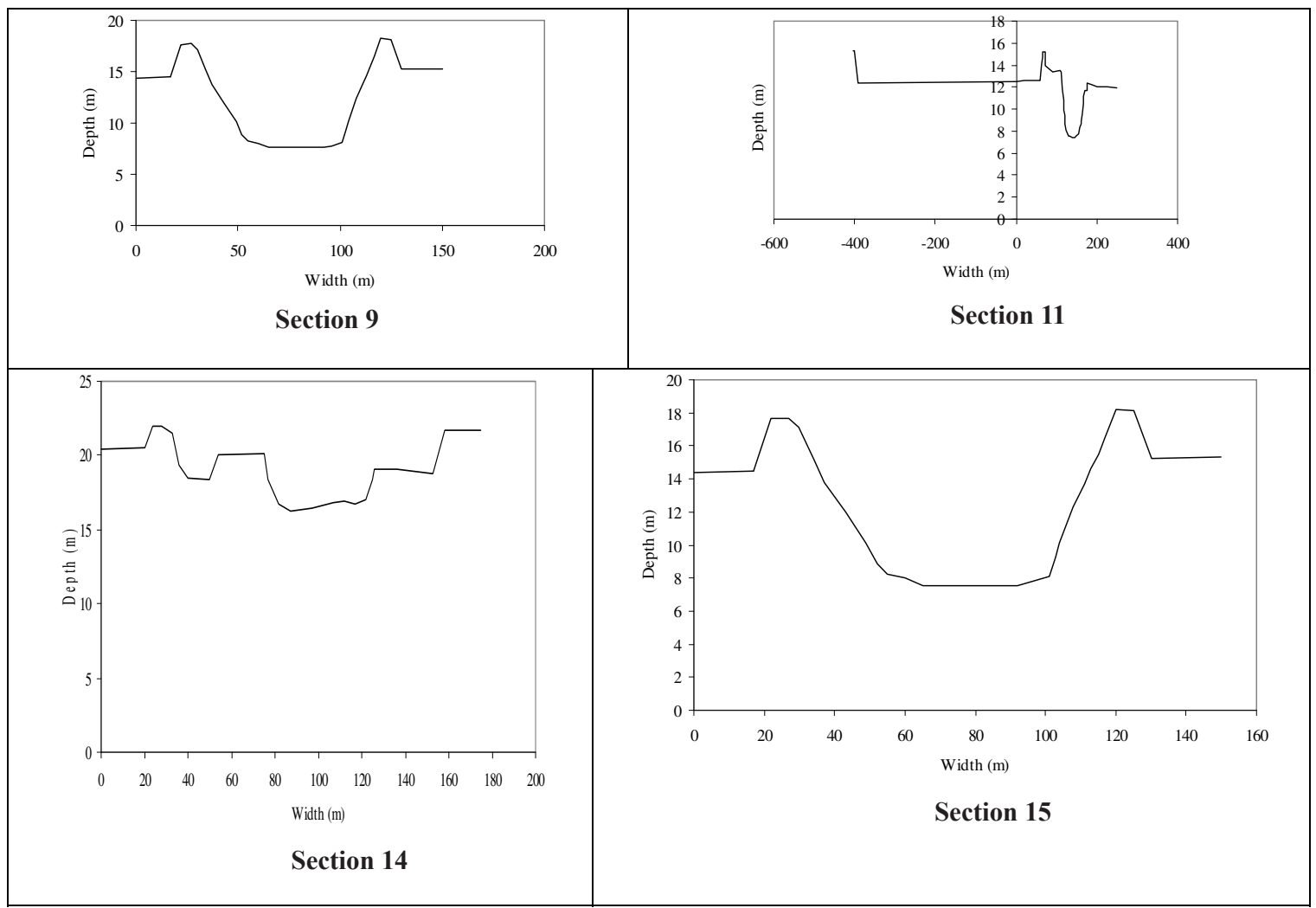

Fig. 4: Cross section and valley character of Little Jamuna River (Section9, 11, 14, 15). (Index Map Fig. 2) 


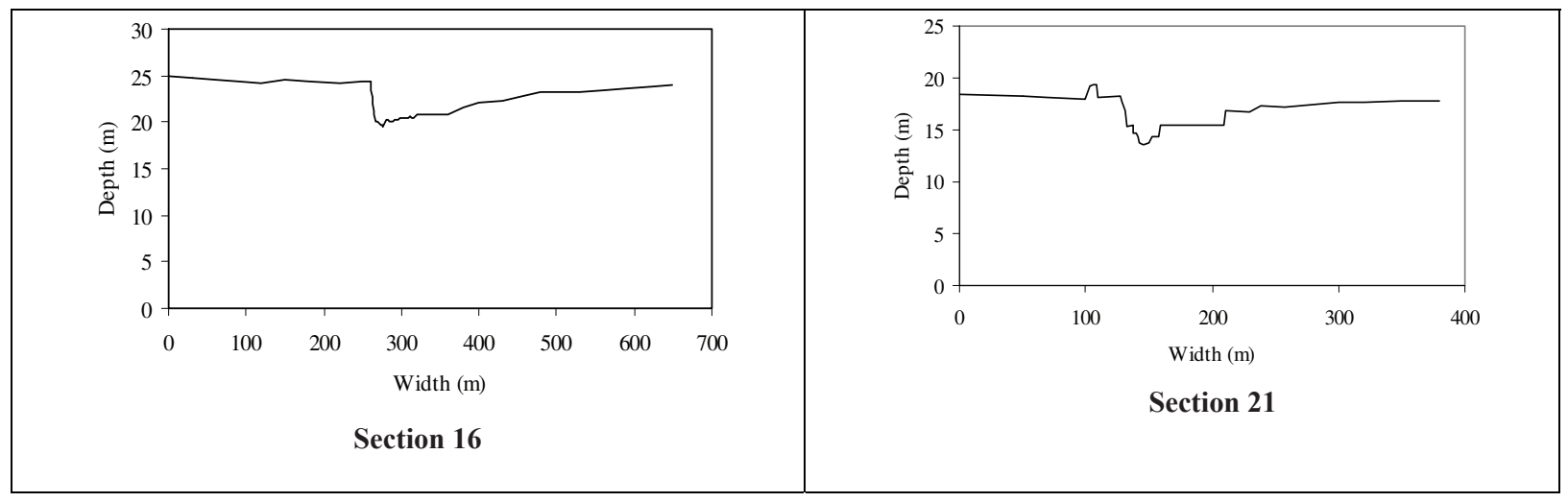

Fig. 5: Cross section and valley character of Karatoya River (Section16, 21). (Index Map Fig. 2)
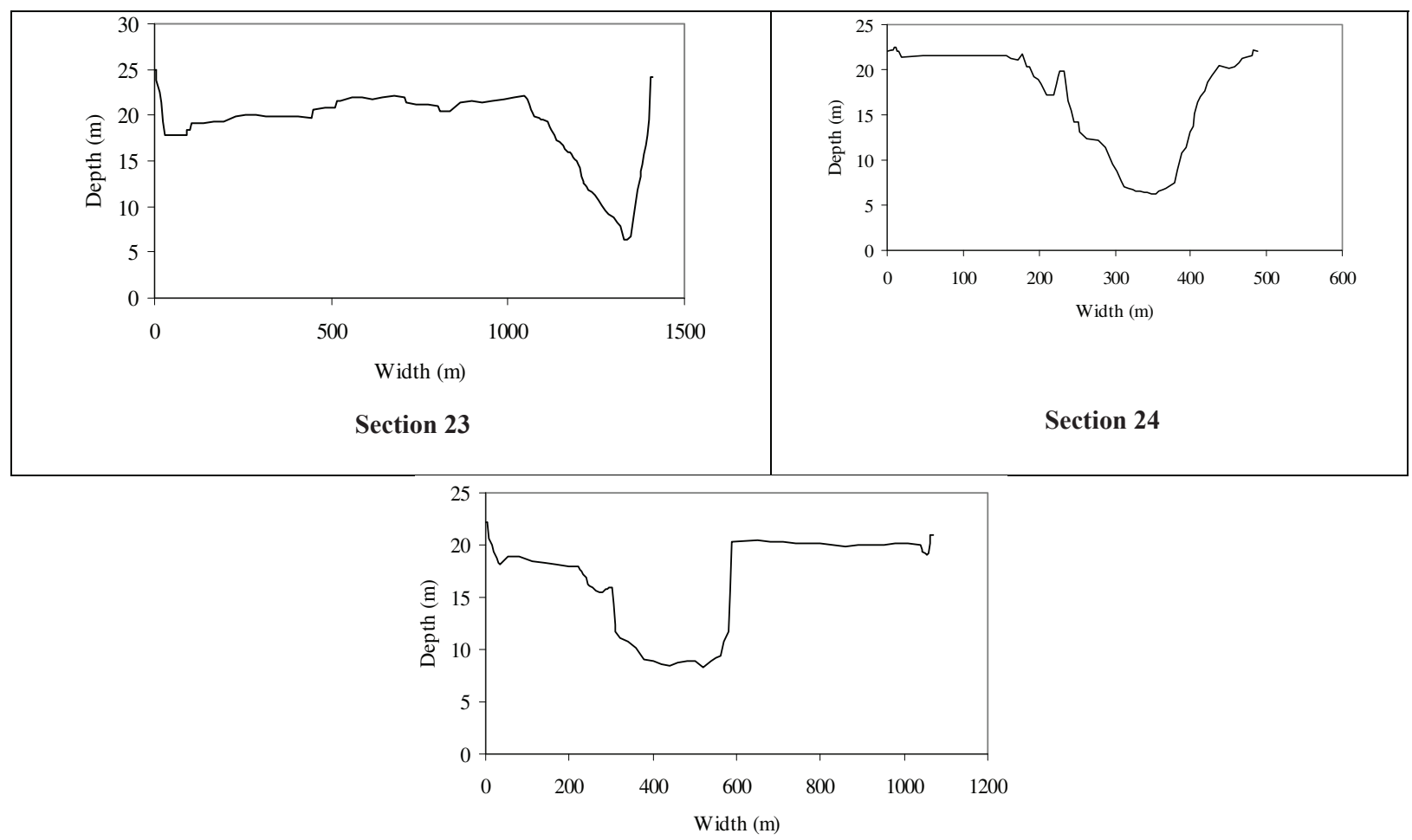

Section 25

Fig. 6: Cross section and valley character of Mahananda River (Section 23, 24, 25). (Index Map Fig. 2)

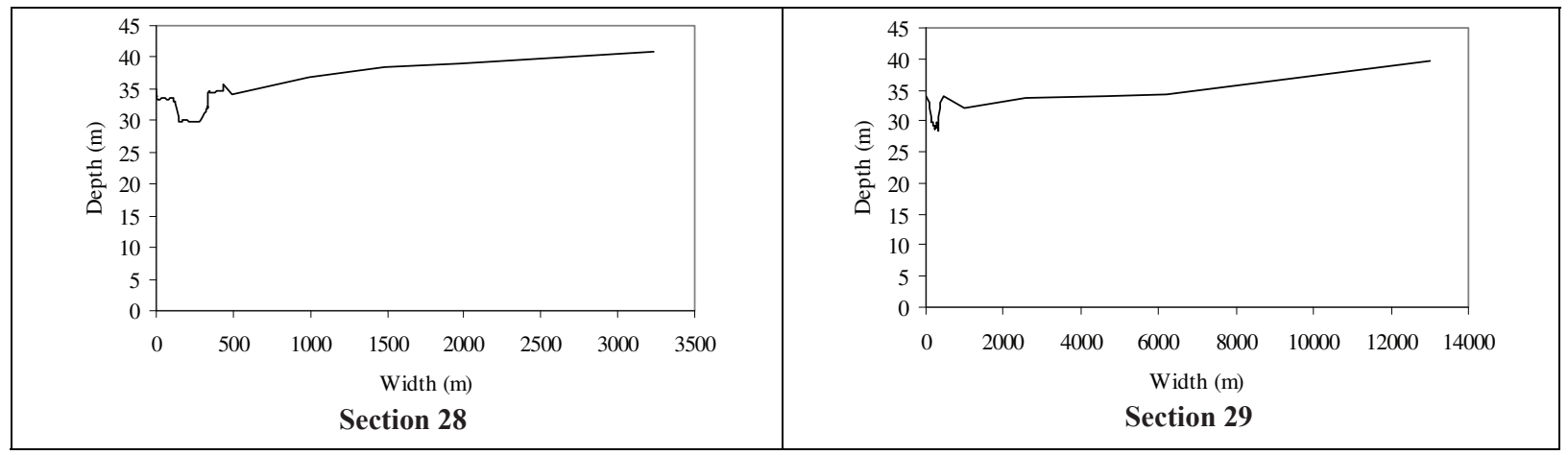

Fig. 7: Cross section and valley character of Punarbhaba River (Section 28, 29). (Index Map Fig. 2) 


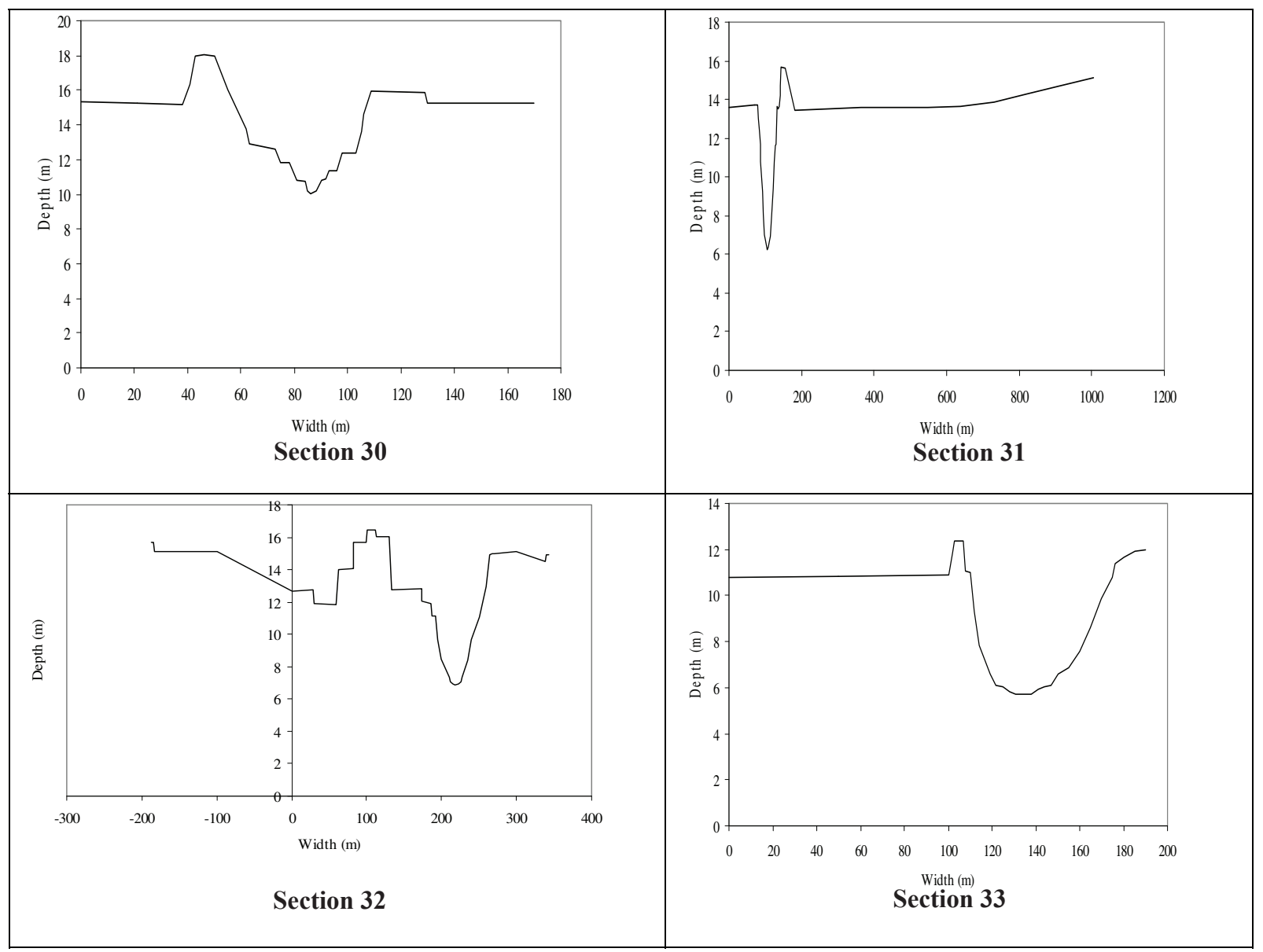

Fig. 8: Cross-section and valley character of Sib-Branai River (Section 30 to 33). (Index Map Fig. 2)

The W/D ratio of the Atrai, Little Jamuna, Karatoya, Mahananda, Punarbhaba and Sib-Baranai Rivers has been calculated in different parts of the study area (Table 1). In case of the Atrai River the W/D ratio in floodplain areas are 30 to 50, within the Barind Tract 10 to 18 and near to the tract is about 20. The W/D ratio of the Little Jamuna River in floodplain areas are 15 to 26, within the Barind 10 to 16 and near to the Barind is about 15. In the Karatoya River the W/D ratio in floodplain areas are 20 to 36 and near to the Barind Tract 10 to 17. In the Mahananda River this W/D ratio in the Barind Tract is about 11, near to the Barind Tract is about 17 and in floodplain areas is about 25. In the Punarbhaba River the same ratio in the upper part of the Tista Fan is about 13, in the middle part 50 to 60 and near to the Barind Tract is about 40 . In the Sib-Baranai River this ratio in the Barind Tract or near to the Barind Tract are 5 to 12 and in the floodplain areas it is about 17.

The W/D ratio of these rivers are much lower within or near to the Barind Tract than it is in nearby floodplain areas. At the same time the channels of these rivers show U-shaped valleys in floodplain areas, nearly U-shaped/or one side steeping valleys near to the Barind and V-shaped valleys within in the Barind Tract. These are indication of the structural upliftment of the Barind Tract as compared to the surroundings.
Earlier studies on the Ganges River system have highlighted the manifestation of regional $\mathrm{E}-\mathrm{W}$ thrusts as knick points in the longitudinal profiles of the rivers in north India (Seeber and Gornitz 1983) and the role of Meghalaya block uplift on the Brahmaputra (Valdiya 1999). On the basis of some geomorphic observations, such as the rivers flow above the general level of the ground, frequent flooding and extensive silting, marshy land, and reduction in delta- building activity in Bengal it was interpreted that the geomorphic change in the Ganges occurred due to epirogenic movement (Ahmed 1963). Geophysical surveys and deep drilling (Sastri et al. 1971, Rao 1973, Karunakaran and Rao 1976, Agarwal 1986) also proved most of these hypotheses. Tectonic influences on the alluvial sedimentation in the Gangetic plains have also been suggested in different works (Singh and Rastogi 1973, Singh and Bajpai 1989, Singh and Ghosh 1994, Singh 1996). Jain and Sinha (2005) also interpreted the active nature of the eastern Gangetic plains. A number of subsurface faults trending NW and NE, transverse to the trend of the Himalaya, were reported and most of these faults are known to be seismogenically active (Krisnaswamy 1962, Valdiya 1976, Dasgupta et al. 1987, GSI, 2000). Many earthquakes occurred in this area in the recent past (Table 2). In 1787, an earthquake occurred near Sirajganj (Table 2). This earthquake changed the courseof the rivers in this region (Morgan and McIntire 1959). 
Table 1: Width/Depth (W/D) ratio of rivers in different parts of the study area. (Index Map Fig. 2)

\begin{tabular}{|c|c|c|c|c|c|}
\hline River & Cross-section No. & Location & Width (m) & Depth (m) & W/D Ratio \\
\hline \multirow{8}{*}{ Atrai } & 1 & Floodplain/Tista Fan & 140 & 9 & 15.56 \\
\hline & 2 & Barind Tract & 120 & 7 & 17.14 \\
\hline & 3 & Barind Tract & 100 & 8 & 12.50 \\
\hline & 4 & Barind Tract & 95 & 9 & 10.56 \\
\hline & 5 & Floodplain/Near to Barind & 100 & 5 & 20.00 \\
\hline & 6 & Floodplain & 200 & 4 & 50.00 \\
\hline & 7 & Floodplain & 210 & 7 & 30.00 \\
\hline & 8 & Floodplain & 250 & 5 & 50.00 \\
\hline \multirow{7}{*}{ Little Jamuna } & 12 & Barind Tract & 25 & 2.5 & 10.00 \\
\hline & 13 & Barind Tract & 80 & 5 & 16.00 \\
\hline & 14 & Floodplain & 130 & 5 & 26.00 \\
\hline & 15 & Floodplain/Near to Barind & 90 & 6 & 15.00 \\
\hline & 9 & Floodplain/Tista Fan & 95 & 10 & 9.50 \\
\hline & 10 & Floodplain/Tista Fan & 90 & 6 & 15.00 \\
\hline & 11 & Barind Tract & 50 & 5 & 10.00 \\
\hline \multirow{7}{*}{ Karatoya } & 16 & Floodplain & 100 & 5 & 20.00 \\
\hline & 17 & Floodplain & 70 & 5 & 14.00 \\
\hline & 18 & Floodplain & 180 & 5 & 36.00 \\
\hline & 19 & Floodplain & 150 & 6 & 25.00 \\
\hline & 20 & Floodplain/Near to Barind & 70 & 4 & 17.50 \\
\hline & 21 & Floodplain/Near to Barind & 60 & 5 & 12.00 \\
\hline & 22 & Floodplain/Near to Barind & 60 & 5.5 & 10.91 \\
\hline \multirow{3}{*}{ Mahananda } & 23 & Floodplain/Near to Barind & 340 & 20 & 17.00 \\
\hline & 24 & Barind Tract & 200 & 17 & 11.76 \\
\hline & 25 & Floodplain & 300 & 12 & 25.00 \\
\hline \multirow{4}{*}{ Punarbhaba } & 26 & Floodplain/Tista Fan & 100 & 8 & 12.50 \\
\hline & 27 & Floodplain/Tista Fan & 250 & 5 & 50.00 \\
\hline & 28 & Floodplain/Tista Fan & 250 & 4 & 62.50 \\
\hline & 29 & Floodplain/Near to Barind & 250 & 6 & 41.67 \\
\hline \multirow{4}{*}{ Sib-Baranai } & 30 & Barind Tract & 50 & 7 & 7.14 \\
\hline & 31 & Barind Tract & 40 & 8 & 5.00 \\
\hline & 32 & Barind Tract & 100 & 8 & 12.50 \\
\hline & 33 & Floodplain & 85 & 5 & 17.00 \\
\hline
\end{tabular}

Another major earthquake occurred on 11 November 1842 withmagnitude Mw 7.3 shook most of Bangladesh. The maximum damage was reported from Pabna. The epicenter of the earthquake was located near Rajshahi. This area also experienced another three strong earthquakes on 23 July, 26 July and 6 August 1845 (Table 2). All three tremors were felt strongly in Bengal and lower Assam. The first quake occurred of Capital Dhaka at approximately 4:30 am local time on 23 July and had a magnitude of 5.9. This was followed by a second tremor at approximately 2:00 am local time on 26 July that had a magnitude of 6.1. The third one was the strongest (7.1) and it occurred on 6 August at approximately 11:30 pm local time. The epicenters of the first two were centered on Sirajganj. The third quake was located in lower Assam. There is also some low magnitude earthquakes occurred in this area in the recent past. An earthquake with magnitude 4.1 occurred on Bangladesh-India border in 5 July, 2008, which was felt in parts of Rajshahi as well as parts of West Bengal in India. The epicenter was located $6.4 \mathrm{~km} \mathrm{W-NW}$ of Rajshahi (Chowdhury 2008), which also indicates the active nature of the areas. Another earthquake with magnitude 4 occurred on Rajshahi-Naogaon border in 29 July, 2011, which was felt in Naogaon, Bogra, Joypurhat and Gaibandha Districts (ANON 2011a, ANON 2011b). The tectonic activities in and around Bengal Basin are also reported in different literatures (Oldham 1882, Oldham 1899, Stuart 1920, Gee 1934, Seeber and Armbruster 1981, Molnar 1987, Chen and Molnar 1990, Bilham and Gaur 2000, Bilham and England 2001, Bilham et al. 2001, Ellis et al. 2001, Mazumdar et al. 2001, Meijde 2004, Akhter and Huque 2004, Biswas and Grasemann 2005). These also indicates that this part is tectonically active. 
Table 2: Records of Earthquakes occurrence in the study area (Source: http://asc-india.org/seismi/seis-west-bengal.htm; Kamaluddin and Rahman 1985, Martin and Szeliga 2010).

2002 - Jayachari-Rajshahi, Bangladesh

Lat. 25.868 N and Lon. 88.874 E, OT=05:40:43 UTC, A moderate earthquake struck northern Bangladesh, on 20 June 2002 at 11:40 AM local time, causing several injuries in the Rajshahi division, Bangladesh. It had a magnitude of 5.1 and was felt for close to 45 -seconds.

1935 - Pabna, Bangladesh

Lat. 24.250 N and Lon. 89.500 E, OT=00:04:02 UTC. Prolonged tremors were felt in much of the Bengal including at Kolkata. It had a magnitude of 6.2. An aftershock occurred on 23 April 1935 and was also widely felt in the region.

1865 - Rajshahi-Murshidabad area, India-Bangladesh border. Lat. $24.400 \mathrm{~N}$ and Lon. 88.700 E. Prolonged tremors were felt in this region.

1845 - Sirajganj, Bangladesh

Bangladesh experienced three strong earthquakes on 23 July, 26 July and 6 August 1845. All three tremors were felt strongly in Bengal and lower Assam. The first quake occurred of Capital Dhaka at approximately 4:30 am local time on 23 July and had a magnitude of 5.9. This was followed by a second tremor at approximately 2:00 am local time on 26 July that had a magnitude of 6.1. The third one was the strongest (7.1) and it occurred on 6 August at approximately 11:30 pm local time. The epicenters of the first two were centered on Sirajganj about $100 \mathrm{~km}$ northwest of Dhaka. The third quake was $265 \mathrm{~km}$ north of Dhaka located in lower Assam.

1842 - Rajshahi, Bangladesh

A major earthquake occurred on 11 November 1842 withmagnitude Mw 7.3 shook most of Bangladesh. The maximum damage was reported from Pabna. The epicenter of the earthquake was located 190 kmwest-northwest of Dhaka near Rajshahi. The intensity of groundshaking in Dhaka was MMV.

1834 - Rangpur area, Bangladesh

Lat. 25.800 N and Lon. 89.400 E. Prolonged tremors were felt in this region.

1834 - Rangpur area, Bangladesh

Lat. 25.800 N and Lon. 89.400 E. Prolonged tremors were felt in this region.

1787 - Sirajganj, Bangladesh

The earthquake of 1787 changed the courseof the rivers in this region.

\section{CONCLUSIONS}

Morphological characteristics of rivers in the area reveal that the Barind Tract is being structurally controlled. U-shaped river valleys before entering into the Barind Tract, $\mathrm{V}$-shaped within the tract, U-shaped again in floodplain areas and nearly U-shaped/or one side steeping valleys near to the Barind are indicate all these are structurally controlled. The W/D ratio of these rivers are much lower within or near to the Barind Tract than it is in nearby floodplain areas. These are also an indication of the structural upliftment of the Barind Tract as compared to the surroundings. The rivers and valleys on the tract are also comparatively more straight, incised and entrenched, and rivers are tightly meandered, more localized, form paired and unpaired terraces, and antecedent in nature, whereas, the rivers in the floodplain are either meandering, braided or anastomosing drainage channels. Many earthquakes in the recent past in this region also indicate the same view about its structural control and neotectonics.

\section{ACKNOWLEDGEMENTS}

The authors would like to express their deep gratitude and cordial thanks to the Director General of the Geological Survey of Bangladesh for giving permission to publish the paper. We also thanks to the helps of the authority of the USGS and IWM.

\section{REFERENCES}

Agarwal, P. N., 1986, A recent earthquake in Northeast India. Proceedings of 2nd International Seminar on Earthquake Prognostics, Berlin, Friedr, Vieweg \& Sons.

Akhter, S. H. and Huque, M. A., 2004, RIS (?) and its impact on Kaptai Hydroelectric Project: A shift in the conceptualistic model on the origin of the Barkal Earthquake. Bangladesh Jour. Geol., v.23, pp. 139-46.

Alam, A. K. M. K., 1995. Neotectonic evidences along the eastern margin of the Barind Tract, Bangladesh. Bangladesh Jour. Geol., v. 14, pp. 25-31. 
Alam, M. K., Hassan, A. K. M. S., Khan, M. R. and Whitney, J. W., 1990, Geological Map of Bangladesh. Geol. Surv. Bangladesh, Dhaka, Scale 1: 1000000.

Alam, M. S. and Paepe, R., 1996, Palaeosols in the Quaternary stratigraphy in north-western Bangladesh, Bangladesh Jour. Geol., v. 2, pp. 15-36.

Alam, M. S., 1993, Stratigraphical and paleoclimatic studies of the Quaternary deposits in northwestern Bangladesh. Unpublished D.Sc. Thesis submitted to Vrije University, Brussels, Belgium, 295 p.

Alam, M. S., Hus, J. and Pape, R., 1997a, Magnetic susceptibility variation of Pleistocene palesol sequence and its significance in paleoclimatic studies in Bangladesh. Proceedings of Inter-PARMAGS Seminar, 1996, pp. 143-151.

Alam, M. S., Hus, J. and Pape, R., 1997b, Magnetostratigraphy of the Quaternary in NW Bangladesh. Proceedings of Inter-PARMAGS Seminar, 1996, pp. 113-127.

Anon, 2011a, Jaypurhata Bhumikompon. The Daily Prothom Alo, dated, July, 30, 2011, p. 19.

Anon, 2011b, Rajshahi - Ranghpur Bibhaga Bhumikompon Anubhuto. The Daily Samakal, dated, July, 30, 2011, e-mail- www.samakal.net., p. 19.

Bilham, R. and England, P., 2001, Lateau “pop-up' in the great 1897 Assam earthquake. Nature, v.10, pp.806-809.

Bilham, R. and Gaur, V. K., 2000, Geodetic contributions to the study of seismotectonics in India. Current Science, v. 79(9), pp.1259-269.

Bilham, R., Gaur, V. K. and Molnar, P., 2001, Himalayan seismic hazard. Science. v. 293, pp.1442-444.

Biswas, S. and Grasemann, B., 2005, Quantitative morphotectonics of the southern Shillong Plateau (Bangladesh/India). Austrian Jour. Earth Sci., Vienna, v. 97, pp. 82-93.

Bull, W. B., 1977, The alluvial fan environment. Prog. Phys. Geogr., v. 1, pp. 222-270.

Burnett, A. W. and Schumm, S. A., 1983, Alluvial river response to neotectonic deformation in Louisiana and Mississippi. Science, v.222, pp. 49-50.

Chen, W. P. and Molnar, P., 1990, Source parameters of earthquakes and intraplate deformation beneath the Shillong Plateau and northern Indo-Burman ranges. Jour. of Geophys. Research, v. 95(B8), pp.12527-12552.

Choudhury, J. R., 2008, Earthquake risk in Bangladesh and mitigatory measures, Bangladesh Eatrhquake Society, Dhaka-1212.

Dasgupta, S., Mukhopadhyay, M. and Nandy, D. R., 1987, Active transverse features in the central portions of the Himalaya. Tectonophysics, v. 136, pp. 255-264.

DeBlieux, C., 1951, Photogeologic study in kent country, Texas. Jour. Oil Gas, v. 50, p. 86.
DeBlieux, C., 1962, Photogeology in Lousiana coastal marsh and swamp, Gulf Coast Assoc. Geol. Soc. Trans,. v. 12, pp. 231-241.

Ellis, M., Gomberg, J. and Schweig, E., 2001, Indian earthquake may serve as analog for New Madrid earthquakes. EOS Transactions, American Geophysical Union, v. 82(32).

Fergusson, J., 1863, On recent changes in the delta of the Ganges. Jour. Geol. Soc., London, v. 19, pp. 322-354.

Gee, E. R., 1934, The Dhubri Earthquake of July 8, 1930. Mem. Geol. Surv. India, v. 65(1), pp. 1-106.

Gregory, D. I. and Schumm, S. A., 1987, The effect of active tectonics on alluvial river morphology. In: Richards, K. (Ed.), River environment and Processes, Institute of British Geographers Special Publication, Blackwell, New-York, v. 18, pp. 41-68.

GSI, 2000, Eastern Nepal Himalaya and Indo-Gangetic Plains of Bihar. In: Narula, P. L., Acharyya, S. K. and Banerjee, J. (eds.), Seismotectonics Atlas of India and Its Environs. Geological Survey of India, pp. 26-27.

Hirst, F. C., 1916, Report on the Nadia Rivers 1915. The Bengal secretariat book depot, Calcutta, India, p. 39.

Holbrook, J. and Schumm, S. A., 1999, Geomorphic and sedimentary response of rivers to tectonic deformation: a brief review and critique of a tool for recognizing subtle epeirogenic deformation in modern and ancient settings. Tectonophysics, v. 305, pp. 287-306.

Huq, M. A., Whitney, J. W., Das, S. K. and Reshad, M. E. A., 1991, Geological map and report of the western part of Rajshahi District, Bangladesh. Geol. Surv. Bangladesh, v. 6, part 1 .

Jain, V. and Sinha, R., 2005, Response of active tectonics on the alluvial Baghmati River, Himalayan foreland basin, eastern India. Geomorphology, v. 70, pp. 339-356.

Kamaluddin, A. F. M. and K. M. Rahman, 1985, The pattern of the structures of rural employment in Bangladesh - A study of the Thanas in Sirajganj. Geographical Essays, Inter India Publications, New Delhi.

Karunakaran, C. and Rao, A. R., 1976, Status of exploration for hydrocarbons in the Himalayan region-contributions to stratigraphy and structure. Miscellaneous PublicationGeological Survey of India, v. 41(5), pp. 1-66.

Khan, A. A., 1991, Tectonics of the Bengal Basin. Jour. Himalayan Geol., v. 2(1), pp. 91-101.

Khan, M. R., 2002, Plate Tectonics and Bangladesh. Jour. Asiatic Soc. Bangladesh Sci., Golden Jubilee Issue, Dhaka, Bangladesh, v. 28(2), pp. 39-62.

Khandoker, R. A., 1987, Origin of elevated Barind-Madhupur areas, Bengal Basin: Result of neotectonic activities. Bangladesh Jour. Geol., v. 6, pp. 1-9.

Krisnaswamy, V. S., 1962, Himalaya in relation to the Ramganga River project. Proceedings of the 2nd Symposium on Earthquake Engineering. University of Roorkee, pp. 411-422. 
Leeder, M. R. and Jackson, J. A., 1993, The interaction between normal faulting and drainage in active extentional basins with examples from the western United States and central Greece. Basin Res., v. 5, pp. 79-102.

Leopold, L. B. and Wolman, M. G., 1957, River channel patterns: braided, meandering and straight. US Geol. Surv. Professional Papers, v. 282-B, pp. 39-85.

Marple, R. T. and Talwani, P., 2000, Evidences for a buried fault system in the Coastal Plain of the Carolinas and VirginiaImplications for neotectonics in the southeastern United States. Geol. Soc. Am. Bull., v.112, pp. 200-220.

Martin, S. and W. Szeliga, 2010, A catalog of felt intensity data for 570 earthquakes in India from 1636 to 2009. Bull. Seism. Soc. Am., v. 100(2), pp. 562-569.

Mazumdar, K., Sengupta, R. and Mishra, M. N., 2001, Neotectonism in Brahmaputra Valley, Assam. National Symposium on Role of Earth Sciences in Integrated Development and Related Societal Issues. Geol. Surv. India, Special Publication, v. 65(III), pp. 227-230.

Meijde, M., 2004, Tsunami in Asia: Cause, impact and prevention, ITC News. International Institute for Geo-Information Science and Earth Observation, The Netherlands, v. 4, pp. 3-6.

Melton, F. A., 1959, Aerial photograph and structural geology. Jour. Geol., v. 67, pp. 352-370.

Molnar, P., 1987, The distribution of intensity associated with the great 1897 Assam Earthquake and bounds on the extent of the rupture zone. Jour. Geol. Soc. India, v. 30(1), pp.13-27.

Monsur, M. H. 1995, An Introduction to the Quaternary geology of Bangladesh, a guide for IGCP 347 Quaternary Stratigraphic Correlation of the Ganges-Brahmaputra sediments. Published by Rehana Akter, 88 Tejkunipara, Tejgaon, Dhaka 1215, Bangladesh.

Monsur, M. H., 1990, Stratigraphical and Palaeomagnetical Studies of some Quaternary deposits of the Bengal Basin, Bangladesh. D.Sc. Thesis, Vrije University. Brussels, Belgium, 241 p. (Unpublished)

Monsur, M. H., Tooley, M. J., Ghatak, G. S., Chandra, P. R., Roy, R. K., Audhikari, P. C. and Akhter, S. K., 2001, A Review and correlation of Quaternary deposits exposed in the Bengal Basin and its surrounding areas. Bangladesh Jour. Geol., v. 20, pp. 33-54.

Morgan, J. P. and McIntire, W. G., 1959, Quaternary Geology of the Bengal Basin, East Pakistan and India. Geol. Soc. Am. Bull., v. 70, pp. 319-342.

Oldham, R. D., 1899, Report of the great earthquake of 12th June, 1897. Mem. Geol. Surv. India, v. 29, 379 p.

Oldham, T., 1882, The Cachar Earthquake of 10th January, 1869. Mem. Geol. Surv. India, v. 19(1), 88 p.

Ollier, C. D., 1981, Tectonics and Landform. Longman Group Limited, Harlow, England, 324 p.

Ouchi, S., 1985, Response of alluvial rivers to slow active tectonic movement. Geol. Soc. Am. Bull., v. 96, pp. 504-515.

Potter, P. E., 1978, Significance and origin of big rivers. Jour. Geol., v. 86, pp. 13-33.

Priyadarshi, N., 2009, Sedimentation by Himalayan Rivers may cause Earthquakes and Land subsidence in Eastern India. Environment and Geology, Source: http:// nitishpriyadarshi.blogspot.com/.

Rao, M. B. R., 1973, The subsurface geology of the Indogangetic plains. Jour. Geol. Soc. India, v. 14, pp. 217-242.

Rashid, B., Islam, S. U. and Badrul I., 2015, Drainage characteristics and evolution of the Barind Tract, Bangladesh. Am. Jour. Earth Sci., v. 1(4), pp. 86-98.

Sastri, V. V., Bhandari, L. L., Raju, A. T. R. and Dutta, A. K., 1971, Tectonic framework and subsurface stratigraphy of the Ganga Basin. Jour. Geol. Soc. India, v. 12, pp. 223-233.

Schumm, S. A., Dumont, J. F. and Holbrook, J. M., 2000, Active tectonics and alluvial rivers. Cambridge University Press, $276 \mathrm{p}$.

Seeber, L, and Armbruster, J. G., 1981, Great detachment earthquakes along the Himalayan arc and long term forecasting in earthquake prediction. An International Review Maurice Ewing Series, Am. Geophys. Union, Washington D. C., v. 4, pp. 259-277.

Seeber, L. and Gornitz, V., 1983, River profiles along the Himalayan arc as indicators of active tectonics. Tectonophysics, v. 92, pp. 335-367.

Singh, I. B. and Bajpai, V. N., 1989, Significance of syndepositional tectonics in the facies development of the Gangetic alluvium Uttar Pradesh. Jour. Geol. Soc. India, v. 31, pp. 61-66.

Singh, I. B. and Ghosh, D. K., 1994, Geomorphology and neotectonic features of Indo-Gangetic plain. In: Dikshit, K. R., Kale, V.S. and Kaul, M. N. (eds.), India: Geomorphic Diversity. Rawat Publications, Jaipur, India, pp. 270-286.

Singh, I. B. and Rastogi, S. P., 1973, Tectonic framework of Gangetic alluvium, with special reference to Ganga River in Uttar Pradesh. Current Science, v. 42, pp. 305-307.

Singh, I. B., 1996, Geological evolution of Ganga plain - An overview. Jour. Palaentological Soc. India, v. 41, pp. 99-137.

Sinha-Roy, S., 2001, Neotectonic significance of longitudinal river profiles: an example from the Banas drainage basin, Rajasthan. Jour. Geol. Soc. India, v. 58(2), pp. 143-156.

SPARRSO, 1984, Landsat MSS FCC Mosaic of Bangladesh. Scale: 1: 1,000,000.

Stevens, G. R., 1974, Rugged landscape, the geology of central New Zealand. A. H. and A. W. Reed, Wellington, 286 p. 
Stuart, M., 1920, The Srimnagol earthquake of 8th July, 1918. Mem. Geol. Surv. India, v. 46(1).

Valdiya, K. S. and Rajagopalan, G., 2000, Large palaeolakes in Kaveri basin in Mysore Plateau: Late Quaternary fault reactivation. Current Science, v. 78(9), pp. 1138-1142.

Valdiya, K. S., 1976, Himalayan transverse faults and folds and their parallelism with subsurface structures of north Indian Plains. Tectonophysics, v. 32, pp. 353-386.

Valdiya, K. S., 1999, Why does river Brahmaputra remain untamed? Current Science, v. 76(10), pp. 1301-1305.

Wallace, R. E., 1967, Notes on stream channels offset by the San Andreas Fault, southern Coast Ranges, California. Stanford Univ. Publ. Geol. Sci., v. 11, pp. 6-20. 